\title{
Roderick the Last of the Goths (1814) de Robert Southey: estructura, análisis y traducción
}

\author{
(Robert Southey's Roderick the Last of the Goths (1814): \\ structure, analysis and translation)
}

\author{
Beatriz Martínez OJeda/José Ramón Ruiz Armillas \\ I22maojb@uco.es/idiomas5@hotmail.com \\ Univ. de Córdoba/Univ. de Cáceres
}

Recibido: 6 de mayo de 2014

Aceptado: 1 de octubre de 2014

Resumen: Trabajo que analiza la obra más relevante del escritor inglés Southey: Roderick the Last of the Goths, poema escrito en 25 cantos y por el que su autor recibiría los elogios más encendidos de la crítica contemporánea, que lo llegaría a encumbrar por encima de Paradise Lost de Milton. Tras una breve introducción a la figura en que se inspira Southey, el rey Don Rodrigo, así como al menor de los poetas lakistas y sus incursiones en la historia de España, llevamos a cabo un análisis del poema, para traducir posteriormente el canto segundo, "Roderick in Solitude", formado por 246 versos libres, que traducidos en alejandrinos, lo que nos permite conservar toda la elegancia y atmósfera del poema original

Palabras clave: Historia de España, Narración poética, Traducción de poesía.

Abstract: This paper analyses the most relevant work written by the English poet Robert Southey: Roderick the Last of the Goths. With this poem, written in 25 cantos, the author gained a reputation with his contemporary critics that raised him over Milton's Paradise Lost. After presenting a brief introduction to Don Rodrigo's figure, that inspired Southey, and also to that of this minor Lake poet and his forays into Spanish history, the present study provides an analysis of the poem and the translation of Canto II, "Roderick in Solitude", composed of 246 lines in free verse. The translation in alexandrines will allow us to maintain the same elegance and atmosphere of the original poem.

Key words: Spanish history, Poetic narration, Translation of poetry. 


\section{INTRODUCCIÓN: DON RODRIGO Y SU FIGURA EN LA LITERATURA}

La figura de Don Rodrigo, rodeada de circunstancias tan singulares, y enmarcada dentro de un ámbito y una época tan cruciales para la historia peninsular, ha llamado desde siempre la atención de científicos y literatos. Todos ellos han ofrecido y siguen ofreciendo sus particulares versiones acerca del carácter y personalidad del mal llamado último rey godo ${ }^{1}$. Llama la atención poderosamente el hecho de que un rey cuyo mandato es tan breve (hay autores que hablan de un año solamente) haya hecho surgir en torno suyo tal cantidad de romances, leyendas y obras dramáticas. Sin duda unos y otras se confunden, se entremezclan y van dando origen a nuevas creaciones noveladas que introducen elementos desconocidos e indemostrables en la biografía de nuestro personaje. Todos los romances que tratan la historia de Don Rodrigo hacen mención, comúnmente, a tres episodios legendarios de su existencia:

a) El referente a la cueva de Hércules, así llamada por primera vez en la Crónica del historiador árabe Ahmed-ar-Razi, también conocido como el moro Rasis; éste cuenta en sus escritos una de las primeras decisiones de Rodrigo al subir al trono: hacer saltar todos los candados echados sobre la puerta de un palacio o casa toledana donde, al decir de los antiguos, se guardaba un secreto; impulsado por su ambición, Rodrigo desea saber qué secreto podía haber sido encerrado allí por un antiguo rey griego dominador de Al-Andalus; tal enigma había sido respetado por los veintisiete reyes anteriores a él, y sólo nuestro personaje osaría contravenir la norma. Dice Rasis:

E él sin ninguna detenencia fue a las puertas de la casa e fi-zolas quebrantar, mas esto fue por muy gran afan, e tantas eran las llaves e los canados que era maravilla. E después que fue abierta entró él e fallaron un palacio en quadra tanto de una parte como de la otra, tan maravilloso que non ha ombre que lo pudiese dezir...e avía hy en él una puerta muy sotilmente fecha e asaz pequeña, e enzima della letras gruesas que dezían en esta guisa QUANDO HERCOLES FIZO ESTA CASA ANDAVA LA ERA DE ADAM EN QUATRO MIL E SEIS AÑOS. E despues que la puerta abrieron fallaron dentro letras abiertas que de-zian: ESTA CASA ES UNA DE LAS MARAVILLAS DE ERCOLES. E despues que estas letras leyeron vieron en el esteo (pilar) una casa fecha en que estaba una arca de plata e ésta era muy

\footnotetext{
1 Decimos "mal llamado" porque modernas investigaciones han descubierto, al menos, dos acuñaciones de moneda posteriores a su reinado que demuestran la existencia de un sucesor para su trono, denominado Aquila, quien continúa la línea sucesoria durante tres años. Se habla incluso de otro rey llamado Ardo, sobre quien se ignora prácticamente todo excepto el nombre.
} 
bien fecha e era labrada de oro e de plata e con pie-dras preciosas e tenía un canado de aljofar tan noble quie ma-ravilla es, e avia en él letras griegas que dezian: O RREY EN SU TIEMPO ESTA ARCA FUERE AVIERTA NON PUEDE SER QUE NON VERA MARAVILLAS ANTE QUE MUERA. E ese Ercoles, el señor de Grecia, supo alguna cosa de lo que avia de venir. ${ }^{2}$

b) El segundo episodio contempla la violación de la hija de Don Julián (u Olián), por el rey Rodrigo. Dice al respecto la Crónica de 1344:

Avia en cepta un conde que era señor de los puertos de allen mar e de aquen mar e avia nombre don Juliano e avia una hija muy fermosa e muy buena doncella... e tanto que esto supo el rrey rodrigo mando decir al conde don Juliano que le mandase traer su fija a Toledo. ${ }^{3}$

c) El tercer episodio, el único de origen cristiano según Menéndez y Pelayo, es el de la penitencia que ha de sufrir el rey después de la derrota de la Sigonera, de Segoyuela o de Guadalete, como vulgarmente la conocemos en la actualidad. Dice el moro Rasis:

E nunca tanto pudieron catar que catasen parte del rey don Rodrigo... e diz que fue señor despues de villas y castillos. Et otros dizen que moriera en el mar, et otros dizen que moriera fuyendo a las montañas y que lo comieron bestias fieras, e más de esto no sabemos, et después a cabo de gran tiempo fallaron una sepultura en Viseo en que estan escritas letras que decían ansí: AQUÍ YACE EL REY DON RODRIGO REY DE GODOS.

Es obvio el interés histórico que estos relatos o narraciones tradicionales encierran, pues se ocupan de un acontecimiento cuyos orígenes se remontan a la época visigótica. De hecho, tres pueblos intervienen en el mantenimiento y difusión de esas leyendas: el mozárabe, el árabe y el cristiano. En particular, el primero de ellos cuenta con dos versiones diferentes sobre la figura de Rodrigo y sobre su reinado; esas dos narraciones, como es lógico, son alimentadas por los partidarios del rey de un lado, y de otro, por sus detractores. En la Cronica Gothorum ${ }^{4}$ del siglo $\mathrm{X}$ se narra cómo Vitiza (y no nuestro personaje) deshonra a la hija de Olián, quien, en venganza, lo traiciona aliándose con los árabes. Vitiza muere antes de que éstos invadan su territorio y Rodrigo hereda la difícil situación,

${ }^{2}$ Pascual de Gayangos, Memoria sobre la autenticidad de la Crónica del moro Rasis. Memorias de la Real Academia de la Historia. Madrid, 1850. Tomo VIII.

${ }^{3}$ Crónica de 1344, en Ramón Menéndez Pidal, Crónicas generales de España. Catálogo de la Real Biblioteca: manuscritos. Madrid, 1898, p. 29.

${ }^{4}$ Cronica Gothorum Pseudoisidoriana. Edición K. Zeumer. 
teniendo incluso que enfrentarse a los propios hijos del difunto que reclaman sus derechos sucesorios. La segunda leyenda nos presenta a Rodrigo como el forzador y, por tanto, causante directo de la gran desgracia. Mientras la primera es aceptada y propagada por los seguidores de Don Rodrigo, hispanorromanos y cristianos ferviente la segunda es difundida por los seguidores de Vitiza, nobles visigodos que viven en armonía con los musulmanes y desean preservar libre de tacha la memoria de su antecesor. ${ }^{5}$

En el siglo XII, un mozárabe toledano residente en León escribe la Crónica Silense, donde se considera a Vitiza un degenerado y un lascivo, pero se atribuye la violación de la hija de Olián al propio Rodrigo. Tal versión, basada en algún modo en la leyenda que los "vitizianos" dejaron entre los árabes, comienza a ser aceptada e incluso popular entre los cristianos. A principios del siglo XIV, el clérigo luso Gil Pérez hace una traducción en portugués de la Crónica del moro Rasis, quien, como es lógico, sigue en su obra el segundo tipo de leyenda mencionado. Surge así la primera versión novelada del tema, que tiene su continuidad en la Crónica de 1344, cuyos puntos fundamentales, en resumen, son:

1. Entrada de Rodrigo en la casa de los candados

2. Violación de la hija de don Julián

3. Don Julián va en busca de la afrentada y la saca del palacio

4. Don Julián visita a Muza y pacta con él

5. Los ejércitos árabes derrotan a don Rodrigo y sus huestes

6 . Se ignora la suerte o paradero del rey después de la batalla definitiva

Pedro del Corral, hacia 1430, escribe la Crónica Sarracina. A través de 518 capítulos narra toda la trama anterior, entremezclada con nuevas aportaciones, al parecer tomadas de la tradición oral. Entre estos elementos novedosos se encuentra ya la leyenda de la penitencia del rey. Sin duda Corral recoge datos ofrecidos por la Crónica de Alfonso III o Cronicón, donde se mencionaba el hallazgo en Viseo de un sepulcro con la inscripción: HIC REQUIESCIT RODERICUS, REX GOTHORUM. Corral, el primer cronista que ahonda en el carácter valiente y combativo del rey, urde una historia, casi una novela de caballerías en la que don Rodrigo es asistido en su huida al llegar a unos parajes deshabitados por un ermitaño, quien se encarga de testificar su penitencia dentro del sepulcro, elemento éste tomado, al parecer, de algún ejemplo piadoso medieval, si bien existen importantes muestras similares en las literaturas europeas.

${ }^{5}$ Aben Abdelhakén, Ajbar Machmuá. Traducción de Emilio Lafuente Alcántara: Colección de obras arábigas de historia y geografía que publica la Real Academia de la Historia. Madrid 1867. 
Esta es, a grandes rasgos, la trayectoria que sigue la historia de Rodrigo hasta el siglo XV, época en que los romances comienzan a tomar verdadera fuerza como género popular, hasta el extremo de crearse ciclos completos alrededor de personajes míticos que, como nuestro héroe, son susceptibles de inspirar al poeta o al creador aventuras y desventuras sin cuento. Y no es extraño que la Crónica del rey don Rodrigo con la destrucción de España, de Pedro del Corral haya servido de fuente inagotable de inspiración a los compositores de nuevos romances, puesto que se publica en frecuentes ediciones: Sevilla 1511, 1522, 1527 y 1587; Toledo, 1549; Alcalá de Henares, 1587; y Valladolid, 1527.

La revolución romántica y su exaltación por los nacionalismos darían un gran impulso a las versiones, aunque en lugar de ser españolas vendrían de Gran Bretaña, ya que de allí provienen los tres poemas que se ocupan del último rey godo:

- The Vision of Don Roderik, de Walter Scott $(1811)^{6}$.

-Count Julian, drama original e histórico, en siete cuadros y en verso (1812) de Walter Savage Landor?

-Roderick the Last of the Goths (1814) poema en verso suelto y en 25 cantos de Robert Southey. ${ }^{8}$

\section{SOUTHEY: SU OBRA Y SU RELACIÓN CON ESPAÑA}

Robert Southey (1774-1843) era el más joven de los denominados "poetas lakistas". Estudiante en Oxford, había sido expulsado de su colegio (la Westminster School) por expresar en un artículo su total rechazo hacia

\footnotetext{
${ }^{6}$ Se trata de un poema de circunstancias que merece ser recordado, más que por su valor intrínseco (que es secundario respecto de otras narraciones poéticas de su autor), por ser un homenaje del gran novelista escocés al heroísmo de los españoles en tiempo de la guerra de la Independencia. Scott se apoyaría en la tradición del palacio encantado de Toledo para hacer pasar a los ojos de Don Rodrigo las futuras vicisitudes de la nacionalidad española, insistiendo más, como era natural, en los triunfos de los ejércitos aliados y en la resistencia popular contra la invasión francesa. No parece haber consultado, para la exposición de la leyenda, más libro que el de Miguel de Luna. A éste también, y a Pedro del Corral, a quien equivocadamente Ilama Rasis, se atuvo Washington Irving en sus Legends of the Conquest of Spain (1826).

${ }^{7}$ Publicada en 1812 sin el nombre de su autor, posiblemente por su altura moral sea su obra más destacada, sin comparación en la poesía inglesa entre el Samson Agonistes (1671) de Milton y Prometheus Unbound de Shelley.

${ }_{8}$ Tras estas tres obras en verso, tema de nuestro trabajo, vendrán otras adaptaciones e imitaciones basadas todas ellas en la figura del rey godo: Washington Irving en sus Legends of the Conquest of Spain (1823) resume y sigue a Pedro del Corral; Trueba y Cosío, en 1830, escribe The romance of history of Spain; Miguel Agustín Príncipe, en 1839, publica un drama que redime la figura denostada del Conde don Julián: Angel de Saavedra, en 1826, compone en Malta su Florinda, nombre que le da a la Cava, la hija de don Julián; José Joaquín de Mora publica en sus Leyendas españolas una visión humorística del tema titulada Don Opas (1840) en plena fiebre romántica Espronceda en su Pelayo (1840) y Zorrilla en El puñal del Godo (1842) y La calentura (1847) tratan también el asunto.
} 
los castigos corporales. Desde ese momento se convertirá en el modelo de estudiante rebelde y proclamará su simpatía hacia la Revolución Francesa en obras como The Fall of Robespierre (1794), escrita en colaboración con Coleridge, y en el drama en verso titulado Joan of Arc: an Epic Poem (1796). En su época fue un poeta famoso y alcanzó prestigio similar a Wordsworth y Coleridge. Aunque se le reconocen propósitos doctrinales bien definidos, maestría para elegir los argumentos y buena dosis de dominio técnico para llevarlos a cabo, su poesía carece de inspiración general, está desprovista del frescor que la imaginación creadora de Wordsworth presta a las cosas sencillas, y no posee el dominio que Coleridge tiene sobre el mundo visionario y misterioso. De los tres poetas posiblemente fuera el más narrador, historicista y anecdótico, con unas ideas políticas muy comprometidas con la ideología tradicionalista, convirtiéndose en un colaborador regular con sus artículos de tema político en la Quarterly Review del partido conservador o "tory". Southey es una figura muy interesante desde el punto de vista español, ya que llegaría a ser nombrado miembro honorario de la Real Academia Española de la Lengua (29-III-1814). Escribió varios poemas breves de tema español que publica en su obra Letters from Spain and Portugal $(1797)^{9}$, donde canta los hechos heroicos de los españoles durante la Guerra de la Independencia; es autor, asimismo, de un buen número de escritos diversos sobre España (destacando, por ejemplo, las famosas alabanzas dedicadas al Poema del Cid) que culminarán con los tres volúmenes de su History of the Peninsular War (1822-1832). Entre las obras de tema español, la crítica especializada se ha ocupado de resaltar el poema titulado Roderick, The Last of the Goths, que publica en 1814 basándose en la crónica de Don Rodrigo, de Pedro del Corral.

Southey iría por primera vez a Portugal después de su matrimonio secreto e invitado por su tío, Herbert Hill, capellán de la colonia británica residente en Lisboa. Pasaría seis meses en la Península lbérica y leyó ampliamente lo mismo literatura española que portuguesa. A su regreso a Inglaterra el matrimonio Southey se establecería en Greta Hall en Keswick, donde Southey mantuvo no solamente a su familia sino a Mrs. Coleridge y Mrs. Lovell. Sus Cartas, escritas durante una corta estancia en España y Portugal, son el resultado de esta primera visita. Haría un segundo viaje a Portugal en 1800-1801, en el que no sólo recoge material para su Historia de Portugal, sino que también representa la introducción en Inglaterra de algunas leyendas medievales españolas. Tradujo The Chronicle of the Cid en 1808, y más tarde escribió una importante History of the Peninsula War (1821).

\footnotetext{
${ }^{9}$ Editadas con el seudónimo de Don Manuel Álvarez Espriella.
} 
A la muerte de Pye, en 1813, el puesto de Poeta Laureado es ofrecido a Walter Scott, quien al rehusarlo se lo asegurará a Southey. Éste sostendrá una violenta controversia con Byron, quien en English Bards and Scotch Reviewers llama a Southey traficante de baladas (a ballad-monger"). La sátira contra Southey se agudiza más, en 1822, en The Vision of Judgement, de Byron. Durante su vida fue conocido principalmente como poeta, aunque actualmente se haya relegado al olvido con excepción de sus poemas cortos y baladas. Sin embargo, su prosa narrativa e histórica es excelente, lúcida, tersa y perfecta. Southey era un hombre culto y bastante al día en nuestra literatura e historia como lo acreditan varias obras suyas, entre ellas sus Cartas de España (1797), sus refundiciones del Amadís de Gaula y del Palmerín de Inglaterra, su Crónica del Cid (1808) y la ya citada Historia de la guerra de la Península. Todo ello le serviría de preparación para su tarea del modo que lo indican las notas de su poema, donde están señaladas casi todas las fuentes, tanto históricas como fabulosas. Poseedor de una colección de libros españoles que debía de ser muy rica a juzgar por las muestras, procuró aprovecharlos todos para dar color a su obra y llenarla de mil curiosidades históricas y geográficas. Mucho menos conocido y traducido que sus dos compañeros de generación e inquietudes, Robert Southey escribió magníficas biografías de autores ingleses, descubriendo también la obra de algunos poetas como Kirke White. Algunos de sus poemas merecen figurar en las mejores antologías, como el titulado "My Days among the Dead are Pased".

\subsection{Estructura y análisis del poema}

Roderick the Last of the Goths fue publicado en dos volúmenes, se trata de un poema épico narrativo formado por veinticinco cantos: 13 en el primero y 12 en el segundo. Cada canto oscila entre los 135 versos (capítulo 9, dedicado a Florinda), y los 422 (capítulo 3, dedicado a Adosinda), según una distribución que atiende más a la importancia que el autor concede al personaje tratado que a la simetría entre capítulos (290, el primero, 256 el segundo, etc.), sin que tampoco se someta a un tipo concreto de estrofa. Cada capítulo va precedido de un nombre, alusivo generalmente al personaje, al lugar en que se desarrolla la acción, o al motivo que la desencadena.

Una lectura atenta nos revela que se trata de verso blanco, ya que tiene un metro predeterminado: cinco pies y diez sílabas en cada verso, pero no está rimado. Sin embargo, aunque muchos versos se pueden considerar pentámetros yámbicos, en algunos otros resulta demasiado forzado al coincidir la sílaba fuerte del pie con una sílaba no solo no acentuada en la palabra, sino difícilmente acentuable sin resultar chocante (por ejemplo, al acentuar el sufijo -ing de los verbos). 
Aparecida la obra en 1814, la avidez del público fue tal que ya contaba con cinco ediciones en 1818. La obra consolidaría la reputación del escritor y haría enmudecer las críticas que se habían desencadenado contra obras anteriores, fundamentalmente contra Thalaba the Destroyer y The Curse of Kehama. En estos dos poemas, Southey, entregándose a todos los impulsos de su genio, y explorando rutas desconocidas expresaba en metros nuevos pensamientos tan profundos y atrevidos que aquellos cuyos oídos no eran capaces de entender sus ritmos y su espíritu era incapaz de elevarse a ideas tales, encontraron muy normal el declarar ininteligible y bárbaro al poeta que no podían ni leer ni comprender.

En el caso que nos ocupa, el poema no les ofrecía los mismos pretextos, viéndose obligados esta vez a repetir las opiniones elogiosas de todos aquellos que se guiaban únicamente por la imparcialidad, afirmando que Roderick the Last of the Goths era el mejor poema épico que se había escrito en inglés hasta ese momento. En efecto, cualquiera que fuera el talento de los rivales contemporáneos de Southey, no estaban tan dotados como él para la epopeya; de este modo, si en The Lost Paradis algunos trozos están por encima del poema de Southey, la fábula, la economía de medios, la verosimilitud, los caracteres y la situación hacen de Roderick, según la opinión de los mejores críticos de la época, un conjunto superior a la obra de Milton.

Era verdaderamente difícil adaptar de un modo más simple y verosímil lo que la Historia nos transmite de Don Rodrigo, unido a las actitudes que el poeta transmitió a su personaje para hacer de él el héroe de su poema; estas actitudes y acciones eran de todo punto naturales y convenientes, destacando el poeta en la descripción de su protagonista con una enorme hondura, sin salirse para ello de la realidad. El autor no pierde cantos enteros en dibujar los rasgos más imperceptibles: pocas palabras, una sola acción y un discurso dan a conocer a Opas, el Conde Don Julián, Abulcacem y Pelayo ${ }^{10}$; en cuanto al carácter de Rodrigo, es tarea difícil

\footnotetext{
${ }^{10}$ Estos son los personajes del poema, tal como los relaciona Southey al comienzo de su obra: Witiza: King of the Wisi-Goths; dethroned and blinded by Roderick.

Theodofred: son of King Chindasvintho; blinded by King Witiza.

Favila: his hrother; put to death by Witiza.

The wife of Favila: Witiza's adulterous mistress.

(These four persons are dead before the action of the poem commences).

Roderick: the last King of the Wisi-Goth: son of Theodofred.

Pelayo: the founder of the Spanish Monarchy: son of Favila.

Gaudiosa: his wife.

Guisla: his sister.

Favila: his son.

Hermesind: his daughter.

Rusilla: widow of Theodofred, and mother of Roderick.

Count Pedro, Count Eudon: Powerful Lords of Cantabria.
} 
elegir un personaje más apropiado para la epopeya, trazarlo con tanta verosimilitud y defenderlo durante toda la obra con tanta naturalidad. En lo que atañe a las costumbres, se revelan totalmente apropiadas y ajustadas a los usos, la religión y los errores del siglo semi-bárbaro en el que transcurre la acción.

El estilo es variado a lo largo de todo el poema, sin por ello dejar de ser noble; se percibe que Southey está imbuido de las bellezas de La Biblia, que a trasvasado a su poema de modo muy acertado, ya que no sólo utiliza los giros enérgicos y las descripciones expresivas que le ofrecen los libros sagrados, sino también su poesía y su majestuosidad.

En lo que concierne a la parte negativa que pudiéramos achacar a la obra de Southey se pueden citar las largas y minuciosas descripciones, a pesar de su justeza y hondura, y a pesar de la elegancia de los versos. Más grave es quizá el hecho de que la acción decae algo en los cantos que preceden a la aclamación de Pelayo. No obstante, todo esto no disminuye ni un ápice el valor del poema de Southey.

\subsection{Traducción del canto segundo de Roderick the Last of the Goths}

De los 25 cantos de que consta el poema Southey, dedica el segundo al personaje principal de su poema: "Roderick in Solitude"; en él trata a fondo la expiación del rey godo...

\section{"Roderick in Solitude"}

TWELVE months they sojourn'd in their solitude,

Alphonso: Count Pedro's son, afterwards king.

Urban: Archbishop of Toledo.

Romano: a Monk of the Caulian Sehools, near Merida.

Abdalaziz: the Moorish Governor of Spain.

Egilona: formerly the wife of Roderiek, now of Abdalaziz.

ABulcacem, Alchman, Ayub, Ibrahim, Magued: Moorish Chiefs.

Orpas: brother to Witiza, and formerly Archbishop of Seville, now a renegade.

Sisibert, Ebba: sons of Witiza and of Pelayo's mother.

Numacian: a renegade, governor of Gegio.

Count Julian: a powerful Lord among the Wisi-Goths, now a renegade.

Florinda: his daughter, violated by King Roderick.

Adosinda: daughter of the Governor of Auria.

Odoar: Abbot of St. Felix.

Siverian: Roderick's foster-father.

Favinia: Count Pedro's wife.

The four latter persons are imaginary. All the others are mentioned in history. I ought, however, to observe, that Romano is a creature of monkish legends; that the name of Pelayo's sister has not been preserved; and that that of Roderick's mother, Ruseilo, has been altered to Rusilla, for the sake of euphony. 
And then beneath the burden of old age

Romano sunk. No brethren were there here

To spread the sackcloth, and with ashes strew

That penitential bed, and gather round

To sing his requiem, and with prayer and psalm

Assist him in his hour of agony.

He lay on the hare earth, which long had been

His only couch; beside him Roderick knelt,

Moistened from time to time his blackened lips,

Received a blessing with his latest breath,

Then closed his eyes, and by the nameless grave

Of the fore-tenant of that holy place

Consigned him, earth to earth.

Two graves are here,

And Roderick transverse at their feet began

To break the third. In all his intervals

Of prayer, save only when he searched the woods

And filled the water-cruise, he laboured there;

"Rodrigo a solas"

Doce meses pasaron los dos en soledad,

y luego tras la carga y el peso de la edad

Romano sucumbió. No estaban sus hermanos

a ponerle el cilicio, y esparcir sus cenizas

en penitencial lecho; para a su alrededor

cantarle su oración, y con rezos y salmos

acompañarlo a él en su hora de agonía.

Yace sobre la tierra que fue su único manto

durante largo tiempo; Rodrigo de rodillas

junto a él de vez en cuando moja sus secos labios, su bendición acepta con su postrer aliento,

luego cierra los ojos, y en la tumba sin nombre

de su predecesor de ese lugar sagrado

rinde el polvo a la tierra.

Hay dos tumbas aquí,

y Rodrigo comienza a sus pies la tercera

abriendo un agujero. En cada intervalo

de oración, salvo cuando buscaba en los bosques

el agua y la comida, trabajaba él allí;

And when the work was done, and he had laid

Himself at length within its narrow sides 
And measured it, he shook his head to think There was no other business now for him.

Poor wretch, thy bed is ready, he exclaimed,

And would that night were come!... It was a task,

All gloomy as it was, which had beguiled

The sense of solitude; hut now he felt

The burthen of the solitary hours:

The silence of that lonely hermitage

Lay on him like a spell; and at the voice

Of his own prayers, he started, half aghast.

Then too, as on Romano's grave he sate

And pored upon his own, a natural thought

Arose within him,... well might he have spared

That useless toil: the sepulcher would he

No hiding place for him; no Christian hands

Were here who should compose his decent corpse

And cover it with earth. There he might drag

His wretched body at its passing hour,

cuando la fosa estuvo se metió dentro de ella, para ver con detalle de largo, como de ancho todo lo que medía, luego a pensar se puso, pues no había otro trabajo que ya pudiera hacer. ¡Pobre aciago, exclamó, tu lecho ya está listo, y no llega la noche!... La tarea que había hecho, por sombría que fuera, había seducido su gusto de aislamiento; sentía ahora en su refugio todo el peso y la carga de horas en soledad: el silencio de aquella aislada reclusión caía en él cual hechizo; e incluso el sonido de sus propias plegarias, casi lo horrorizaba. Cuando sentado sobre la tumba de Romano contemplaba la suya, un pensamiento innato le venía a la mente..., bien podía haberse ahorrado este inútil esfuerzo: no tendría la fosa que guardarle sitio a él; no habría manos cristianas para dar buen reposo a su propio cadáver, y cubrirlo con tierra. Allí podría arrastrar su miserable cuerpo en la hora de su muerte,

And there the Sea-Birds of her heritage Would rob the worm, or peradventure seize, 
Ere death had done its work, their helpless prey. Even now they did not fear him: when he walked Beside them on the beach, regardlessly They saw his coming; and their whirring wings As if, being thus alone, humanity Had lost its rank, and the prerogative Of man was done away.

For his lost crown

And sceptre never had he felt a thought Of pain: repentance had no pangs to spare For trifles such as these,... the loss of these Was a cheap penalty:... that he had fallen Down to the lowest depth of wretchedness, His hope and consolation. But to lose His human station in the scale of things,... To see brute Nature scorn him, and renounce Its homage to the human form divine; ... Had then almighty vengeance thus revealed

y las aves marinas hurtarían a los vermes su herencia, o quizá tomando por la fuerza, a su indefensa presa, antes de que la muerte su labor completara. Ahora ya no le temen: cuando va caminando a su lado en la playa, lo ven pasar de cerca; $y$ sus alas lo rozan cual si estuviera solo en esta humanidad, ya perdido su rango y las prerrogativas de un hombre acabado.

Por su perdido cetro y corona, jamás tuvo un pensamiento de pena: la aflicción no vierte jamás lágrimas por esas nimiedades..., la pérdida de aquello era escasa sanción:..., lo que había caído en todo lo más hondo de las adversidades, su esperanza y consuelo. jPero eso de perder su categoría humana en la escala de cosas..., ver la bruta Natura vejarlo, y renunciar al homenaje humano cual forma celestial..., la agobiante venganza así le revelaba

His punishment, and was he fallen indeed Below fallen man, $\ldots$ below redemption's reach, $\ldots$ 
Made lower than the beasts, and like the beasts

To perish!... Such temptations troubled him

By day, and in the visions of the night;

And even in sleep he struggled with the thought,

And waking with the effort of his prayers

The dream assailed him still.

A wilder form

Sometimes his poignant penitence assumed,

Starting with force revived from Intervals

Of calmer passion, or exhausted rest;

When floating back upon the stream of thought

Remembrance to a self-excusing strain

Beguiled him, and recalled in long array

The sorrows and the secret impulses

Which to the abyss of wretchedness and guilt

Led their unwary victim. The evil hour

Returned upon him, when reluctantly

Yielding to worldly counsel his assent,

su castigo, su caída era en verdad más baja

que la caída del hombre..., sin haber redención...,

peor que la de las bestias, y lo mismo que ellas

perecería!... Tales ideas lo atormentaban

durante el día, y la noche la pasaba en visiones;

e incluso hasta en sus sueños combatía estas ideas,

y despertado a causa de su intensa plegaría

el sueño lo seguía afligiendo.

a veces asumía su aguda penitencia,

Una silueta agreste

iniciada con fuerza y avivada a intervalos

de apacible pasión, o descansos exhaustos;

al volver con las olas de sus ideas convulsas,

un recuerdo engañoso se esforzaba en llevarlo

a excusarse, evocando con gran diversidad

todas las amarguras y secretos impulsos

que a un abismo de culpa e infortunio lleváronlo

como víctima incauta. La fatídica hora

de nuevo ante él volvía, cuando con reticencia,

complaciendo consejos de este mundo, pactó

In wedlock to an ill-assorted mate

He gave his cold unwilling hand: then came 
The disappointment of the barren bed, The hope deceived, the soul dissatisfied, Home without love, and privacy from which Delight was banished first, and peace too soon Departed. Was it strange that when he met A heart attuned,... a spirit like his own, Of lofty pitch, yet in affection mild,

And tender as a youthful mother's joy,...

Oh was it strange if at such sympathy

The feelings which within his breast repelled

And chilled had shrunk, should open forth like flowers

After cold winds of night, when gentle gales

Restore the genial sun! If all were known,

Would it indeed he not to he forgiven?...

(Thus would he lay the unction to his soul,)

If all were truly known, as Heaven knows all, Heaven that is merciful as well as just,... A passion slow and mutual in its growth,

bodas por interés y no bien avenidas; dio su fría y renuente mano: luego llegó la gran desilusión de un lecho infecundo, la esperanza engañada, el alma insatisfecha, un hogar sin amor, y del que se expulsó lo primero al placer, y del que se marchó la paz pronto. Fue extraño que cuando él encontró un corazón acorde..., un espíritu armónico, de elevado carácter, además de apacible, tierno, a la vez que alegre, cual de una joven madre..., ¿acaso era extraño que esta condolencia avivara ternuras que repelía su pecho y el frío había contraído, abriendo cual las flores tras el frío viento oscuro, cuando el vendaval suave restaura el sol amable? ¿Si se supiera todo, no acabaría en verdad siendo él perdonado?... (Así podría lograr la unción para su alma); si todo se supiera, como lo sabe el Cielo, el Cielo que es clemente tanto como es ecuánime... Una pasión gradual y mutua al ir naciendo,

Pure as fraternal love, long self-concealed, And, when confessed in silence, long controlled; 
Treacherous occasion, human frailty, fear

Of endless separation, worse than death,

The purpose and the hope with which the Fiend

Tempted, deceived, and maddened him; - but then

As at a new temptation would he start,

Shuddering beneath the intolerable shame,

And clinch in agony his matted hair;

While in his soul the perilous thought arose,

How easy 'twere to plunge where yonder waves

Invited him to rest.

Oh for a voice

Of comfort, - for a ray of hope from Heaven!

A hand that from these billows of despair

May reach, and snatch him ere he sink ingulfed!

At length, as life, when it hath lain long time

Oppressed beneath some grievous malady,

Seems to rouse up with re-collected strength,

And the sick man doth feel within himself

pura cual fraternal amor desde su forja,

y cuando confesada, domeñada en silencio;

la traidora ocasión, fragilidad humana,

miedo de cisma eterno, que es peor que la muerte...,

la esperanza y el ánimo con la que tienta el diablo,

lo embauca y lo enfurece...; luego en el cobertizo,

cual nueva tentación que pudiera empezar

se estremece ante la insufrible vergüenza,

y agarra en su agonía su apelmazado pelo,

mientras se eleva en su alma la idea arriesgada:

¡cuán fácil que sería zambullirse en las olas

que al reposo lo invitan!

¡Qué voz consoladora...,

qué rayo de esperanza proveniente del Cielo!

Una mano que pueda de esta nube arrancarlo

de desesperación antes de que lo engullan.

Por fin, como la vida que ha estado largo tiempo

9oprimida a causa de algún mal doloroso,

parece despertarse y recuperar fuerzas,

y siente el hombre enfermo renacer ante él

A second spring; so Roderick's better mind

Arose to save him. Lo! the western sun 
Flames o'er the broad Atlantic; on the verge

Of glowing ocean rests; retiring then,

Draws with it all its rays, and sudden night

Fills the whole cope of heaven. The penitent

Knelt by Romano's grave, and, falling prone,

Clasped with extended arms the funeral mould.

"Father!" he cried, "companion! only friend

When all beside was lost! thou, too, art gone;

And the poor sinner, whom from utter death

Thy providential hand preserved, once more

Totters upon the gulf. I am too weak

For solitude, - too vile a wretch to bear

This everlasting commune with myself.

The Tempter hath assailed me; my own heart

Is leagued with him; Despair hath laid the nets

To take my soul, and Memory, like a ghost,

Haunts me, and drives me to the toils. O Saint,

While I was blest with thee, the hermitage

un segundo esplendor; así sintió Rodrigo

levantarse su ánimo y salvarlo. El ocaso

llameaba en el ancho Atlántico; al borde del fulgente

vestigio del océano; retirándose entonces

dibujó con sus rayos una súbita noche,

llenando por completo el cielo. El penitente

se arrodilló en la tumba de Romano, cayendo,

abrazó con sus brazos la losa funeraria.

¡Padre mío!, gritó; ;compañero, amigo único,

cuando lo perdí todo! Tú también te marchaste,

y el pobre pecador a quien de total muerte

tu providencial mano otra vez preservara

de caer en el abismo. También estoy muy débil

para la soledad..., triste para llevar

este perpetuo diálogo siempre conmigo mismo.

El seductor me asalta; mi propio corazón

conspira contra mí; mi angustia crea espectros

que se adueñan de mi alma, cual si fuera un fantasma,

la memoria me asalta llevándome a sus redes.

¡Santo asceta contigo, mientras viví en la ermita

Was my sure haven! Look upon me still,

For from thy heavenly mansion thou canst see 
The suppliant; look upon thy child in Christ. Is there no other way for penitence? I ask not martyrdom; for what am I That I should pray for triumphs, the fit meed Of a long life of holy works like thine; Or how should I presumptuously aspire To wear the heavenly crown resign'd by thee, For my poor sinful sake? Oh point me thou Some humblest, painfullest, severest path; Some new austerity, unheard of yet In Syrian fields of glory, or the sands Of holiest Egypt. Let me hind my brow With thorns, and barefoot seek Jerusalem, Tracking the way with blood; there day by day Inflict upon this guilty flesh the scourge, Drink vinegar and gull, and for my bed Hang with extended limbs upon the Cross, A nightly crucifixion!... anything

fuiste un refugio firme! Extiende todavía, de tu mansion celeste una mirada amiga a quien te invoca; mira a tu hijo en Cristo. ¿Para él no hay acaso otra vía de penitencia? No demando el martirio; ¿quién soy para aspirar a lograr los honores que recompensar pueden a una larga vida de obras santas cual tú?; ¿o, qué derecho tengo para osar aspirar a llevar la corona que tú sumisamente, en mi nombre purgaste? Enséñame el camino el más humilde, austere y también doloroso; una austeridad nueva, y sin embargo insólita en los gloriosos campos de Siria, o las arenas del Egipto sagrado. iPermite que mi frente porte espinas, y lave pies en Jerusalén, sellando mi camino con mi sangre, azotando cada día mi carne culpable y pecadora; bebiéndome el vinagre y la hiel, y eligiendo como cama una cruz, donde alargue mis miembros, sufriendo cada noche crucifixión!.., ;cualquier

Of action, difficulty, bodily pain,

Labour and outward suffering;... anything 
But stillness and this dreadful solitude! Romano! Father! let me hear thy voice In dreams, O sainted Soul! or from the grave Speak to thy penitent; even from the grave Thine were a voice of comfort.

Thus he cried,

Easing the pressure of his burthened heart With passionate prayer; thus poured his spirit forth, Till the long effort had exhausted him, His spirit failed, and laying on the grave His weary head, as on a pillow, sleep Fell on him. He had prayed to hear a voice Of consolation, and in dreams a voice Of consolation came. Roderick, it said,... Roderick, my poor, unhappy, sinful child, Jesus have mercy on thee!... Not if Heaven Had opened, and Romano, visible In his beatitude, had breathed that prayer...;

duro trabajo, apuros, torturas corporales, penas y sufrimientos...; todo lo imaginable salvo este silencio y su atroz soledad! ¡Romano! ¡Padre mío!, jdéjame oír tu voz en sueños, o alma santa!, deja que tu voz salga de la tumba y que hable a este penitente, sería voz de consuelo.

Así gritaba el hombre, la opresión aliviando de su angustiado pecho con encendidas súplicas; sintió así que su espíritu acusando el esfuerzo y exhausto a causa de él, desfallecía de nuevo, reposó en la lápida su agotada cabeza, cual si fuera una almohada, cayendo allí de sueño. Había rogado oír una voz de consuelo, y en sueños una voz de consuelo llegó. ¡Rodrigo, le decía..., Rodrigo, mi infeliz, pecador desdichado, de ti Jesús se apiade!... Si estuvieran los cielos abiertos, y Romano, visible en su gloria, por ti habría rezado esa oración que pides...;

Not if the Grave had spoken, had it pierced So deeply in his soul, nor wrung his heart 
With such compunctious visiting, nor given So quick, so keen a pang. It was that voice Which sung his fretful infancy to sleep

So patiently; which soothed his childish griefs;

Counseled, with anguish and prophetic tears,

His headstrong youth. And lo! his mother stood

Before him in the vision: in those weeds

Which never from the hour when to the grave

She followed her dear lord Theodofred

Rusilla laid aside; hut in her face

A sorrow that bespake a heavier load

At heart, and more unmitigated woe,...

Yea a more mortal wretchedness than when

Witiza's ruffians and the red-hot brass

Had done their work, and in her arms she held

Her eyeless husband; wiped away the sweat

Which still his tortures forced from every pore;

Cooled his scorched lids with medicinal herbs,

De haber la tumba hablado, habría ablandado tan hondamente su alma, como su corazón, donde tantos pesares pululaban, rodeándolo de repentina angustia. Era esa aquella voz la que oyera en su infancia mitigando sus llantos con dulzura al dormir; calmó penas pueriles; recondujo sus ansias y proféticas lágrimas, su juventud obstinada i $Y$ ved!, su madre allí ante él parada estaba: con sus ropas de luto que llevara en la hora en que escoltó a la tumba a su querido esposo el noble Teodofredo, Recilona, ${ }^{11}$ a un lado; denotaba en su cara una pena anunciando una carga más honda en el alma, además de una aflicción completa..., una mortal desgracia que el día en que los rufianes de Witiza con hierros y metales candentes hicieron su trabajo, y en sus brazos sostuvo a su esposo invidente; su sudor enjugaba ya que por las torturas le salía por los poros; refrescando con hierbas sus abrasados párpados,

\footnotetext{
${ }^{11}$ Don Rodrigo era hijo de Teodofredo, duque de Córdoba, y Recilona.
} 
And prayed the while for patience for herself And him, and prayed for vengeance too, and found Best comfort in her curses. In his dream, Groaning he knelt before her to beseech Her blessing, and she raised her hands to lay A benediction on him. But those hands Were chained, and easting a wild look around, With thrilling voice she cried, Will no one break These shameful fetters? Pedro, Theudemir, Athanagild, where are ye? Roderick's arm Is withered,... Chiefs of Spain, hut where are ye? And thou, Pelayo, thou our surest hope, Dost thou too sleep?... Awake, Pelayo!... up!... Why tarriest thou, Deliverer?... But with that She broke her bonds, and lo! her form was changed! Radiant in arms she stood! a bloody Cross Gleamed on her breast-plate, in her shield displayed Erect a Lion ramped; her helmed head Rose like the Berecynthian Goddess crowned With towers, and in her dreadful hand the sword

rezando mientras tanto para tener aguante ella y él, y esperar que pudieran vengarse, y encontrar bienestar ella en el infortunio. Gimió él en su sueño, ante ella arrodillándose su bendición pidiendo, y alzó ella sus manos para así bendecirlo. Pero estaban sus manos con hierros, y lanzando triste mirada en torno, gritó con voz brutal: ¿Nadie vendrá a romper estas viles cadenas? Pedro, Teodomiro, Atanagildo, do estais? El brazo de Rodrigo está apagado... Jefes de España, ¿dónde estais? ¿Y tú, Pelayo, nuestra más segura esperanza, No duermes demasiado?... Despiértate, Pelayo! ¿Por qué te atrasas tanto, Salvador?... ¡Pero en eso, rompe sus ligaduras, vedla cambiar de aspecto! ¡Radiante entre sus brazos una sangrienta cruz brilla en su coraza, su ewcudo está adornado de un león rampante; su yelmo está ornado 
como el de Berecinta ${ }^{12}$, la diosa coronada con torres, y la espada en su terrible mano

Red as a fire-brand blazed. Anon the tramp Of horsemen, and the din of multitudes Moving to mortal conflict, rung around; The battle-song, the clang of sword and shield, War-cries and tumult, strife and hate and rage, Blasphemous prayers, confusion, agony, Rout and pursuit and death; and over all The shout of Victory ... Spain and Victory! Roderick, as the strong vision mastered him, Rushed to the fight rejoining: starting then, As his own effort burst the charm of sleep, He found himself upon that lonely grave In moonlight and in silence. Hut the dream Wrought in him still; for still he felt his heart Pant, and his withered arm was trembling still; And still that voice was in his ear which called On Jesus for his sake.

Oh might he hear

That actual voice! and if Rusilla lived,...

If shame and anguish for his crimes not yet

roja como una antorcha. Al instante el carro con hombres y caballos, y el fragor de la turba corriendo a mortal lucha, suena a su alrededor; el canto de batalla, choque de espada y tarja, gritos de Guerra, estruendo, combate, odio y rabia, blasfemias y oraciones, confusión, agonía, derrota, acoso y muerte; y dominando todo el grito de victoria... ;España y victoria! Rodrigo ante la fuerte vision que lo domina,

${ }^{12}$ Según el Dictionnaire de la fable de François Noel (Paris: chez Le Normand, 1801, Tome I, p. 160) «BERECYNTHE, ou BERECYNTHIE, surnom de la mère des dieux, pris de la montagne de Bérécynthe en Phrygie, où elle était née, et où elle avait un temple. Le culte de Bérécynthe était fort célèbre dans les Gaules, et l'on voit dans Grégoire de Tours qu'il subsistait encore au quatrième siècle. On la promenait à travers les champs et les vignes, sur un char traîné par des bœufs, pour la conservation des biens de la terre; et le peuple suivait en foule, chantant et dansant devant la statue». Se trata de Cibeles (Rea para los griegos), hermana y esposa de Saturno, figurando entre los poetas con nombres diversos Díndima, Berecinta e Idea, en recuerdo de tres montañas de la Frigia (Dindima, Berecinta e Idea) donde era principalmente adorada. 
corre alegre a la lucha: llega cogiendo impulso, pero su propio esfuerzo rompe el mágico sueño, se encuentra solo sobre la solitaria tumba por la noche en silencio. El sueño, sin embargo, todavía lo agitaba; siente aún su corazón jadear, y su atrofiado brazo aún temblaba; y otra vez esa voz que por él imploraba a Jesús su clemencia.

¡Si en realidad pudiera

oír esa voz! Y si Recilona aún viviera..., si la pena y la angustia por los crímenes de él

Had brought her to the grave,... sure she would bless Her penitent child, and pour into his heart Prayers and forgiveness, which, like precious balms, Would heal the wounded soul. Nor to herself Less precious, or less healing, would the voice That spake forgiveness flow. She wept her son For ever lost, cut off with all the weight Of unrepented sin upon his head,

Sin which had weighed a nation down: what joy To know that righteous Heaven had in its wrath Remembered mercy, and she yet might meet The child whom she had borne, redeemed, in bliss! The sudden impulse of such thoughts confirmed That unacknowledged purpose, which till now Vainly had sought its end. He girt his loins, Laid blessed Mary's image in a cleft Of the rock, where, sheltered from the elements, It might abide till happier days came on, From all defilement safe; poured his last prayer Upon Romano's grave, and kiss $u$ the earth Which covered his remains, and' wept as if At long leave-taking, then began his way.

no la hubieran llevado a la tumba..., podría ella bendecir a su hijo, y vertería en su pecho plegarias y perdones, que cual preciosos bálsamos sanarían su alma herida. A la vez que preciosos para ella sanaríanla, si hablárale a ella la voz que el perdón daba. Ella lloró por su hijo perdido para siempre, caído por todo el peso 
de un tenaz pecador en su obstinada testa, pecado que había ahogado a una nación entera: iqué alegría saber que el recto cielo, en su ira, invocara la gracia,y ella aún ver pudiera al niño que pariera, redimido en la dicha! El repentino impulso de tal pensar confirma un ignoto propósito, el cual hasta este instante en vano había buscado. Se ata la cintura, deja la santa imagen de María en una grieta de la roca, allí donde a salvo de inclemencias, podia esperar que días más felices llegaran, a salvo de impurezas; dice su plegaría última a Romano en su tumba, y acaricia la tierra que cubre sus despojos, y llorando cual si fuese el último adiós, comienza su camino.

\section{CONCLUSIÓN}

Southey es uno de los primeros representantes del cosmopolitismo literario, de la curiosidad universal, medio erudita, medio poética. Lector y bibliófilo incansable, sabedor de muchas lenguas y de muchas literaturas, especialmente de la nuestra, fue sin duda el primer hispanista inglés de su tiempo. En sus tentativas épicas los poemas de Southey recorren casi todo el ciclo de la geografía y de la historia. Actualmente no se estiman mucho estos poemas, a pesar de la brillantez y opulencia del estilo; quizá la misma perfección con que Southey escribía la prosa contribuye a que sus obras en verso parezcan afectadas y un tanto pedantes. Pero, en cualquier caso, no se le puede negar el mérito de iniciador, que fue grande, ya que él más que cualquier otro trabajó para poner en contacto con la literatura universal el genio inglés, tan excesivamente apegado siempre a su propio fondo y recursos, antítesis perfecta del comprensivo y flexible genio alemán.

La importancia del tema de Don Rodrigo para los escritores de lengua inglesa no menguaría en importancia con el paso del tiempo; en efecto, el escritor norteamericano Washington Irving, durante su estancia en España, volvió a referirse a Don Rodrigo en sus Legends of the Conquest of Spain $(1826){ }^{13}$ Crónicas moriscas: Leyendas de la conquista de España (1835), donde Irving desarrolla en 18 capítulos y 95 páginas la historia del rey godo, añadiéndoles dos Illustrations of the Legend: "The Tomb of Roderick" y "The Cave of Hercules"; dado que el canto que hemos traducido se ocupaba del

${ }^{13}$ Traducidas al español por el ingeniero y profesor venezolano Luis Miguel Báez Díaz, exministro de obras públicas de su país, en 1974, reeditándose en 2002. 
retiro de Rodrigo y su arrepentimiento, que Irving recoge siguiendo a algunos historiadores en Mérida, por su interés transcribimos la primera ${ }^{14}$ :

The Tomb of Roderick.

The venerable Sebastiano, Bishop of Salamanca, declares that the inscription on the tomb at Viseo, in Portugal, existed in his time, and that he had seen it. A particular account of the exile and hermit life of Roderick is furnished by Berganza, on the authority of Portuguese chronicles.

Algunos historiadores Portugueses aseguran, que el Rey Rodrigo, perdida la batalla, huyó a tierra de Mérida, y se recogió en el monasterio de Cauliniano, en donde, arrepentido de sus culpas, procuro confesarlas con muchas lágrimas. Deseando mas retiro, y escogiendo por compañero a un monje llamado Román, y elevando la Imagen de Nazareth, que Cyriaco monje de nación griego había traído de Jerusalén al monasterio de Cauliniano, se subió a un monte muy áspero, que estaba sobre el mar, junto al lugar de Pederneyra. Vivió Rodrigo en compañía de el monje en el hueco de una gruta por espacio de un año; después se pasó a la ermita de san Miguel, que estaba cerca de Viseo, en donde murió y fue sepultado.

Puedese ver esta relación en las notas de Don Thomas Tamayo sobre Paulo deacano. El chronicón de san Millán, que llega hasta el año 883, deze que, hasta su tiempo, si ignora el fin del Rey Rodrigo. Pocos años después el Rey Don Alonzo el Magno, habiendo ganado la ciudad de Viseo, encontró en una iglesia el epitafio que en romance dize_aquí yaze Rodrigo, último Rey de los Godos.-Berganza, 1. i. c. 15.

\section{REFERENCIAS BIBLIOGRÁFICAS}

BERNHARDT-KABISCH, Ernest, Robert Southey. Boston: G. K. Hall, 1977.

Coletes Blanco, Agustín; LASPRa RodríGuez, Alicia, Libertad frente a Tiranía: Poesía inglesa de la Guerra de la Independencia (18081814). Antología bilingüe, Selección, traducción y estudios de A. C. B. y A. L. R. Madrid: Espasa-Calpe, 2014.

FitzGerald, Maurice, Poems of Robert Southey. Oxford: Oxford University Press, 1909.

FREMONT-BARNES, Gregory, The Napoleonic Wars: The Peninsular Wars 1807-1814. Oxford: Osprey Publishing, 2002.

HeINOWITZ, Rebecca Cole, Spanish America and British Romanticism, 17771826. Edinburgh University Press, 2010.

IRVING, Washington, Legends of the conquest of Spain. 1826.

${ }^{14}$ Redactada en inglés y español por Irving, para mantener el encanto de la narración en esta última lengua nos hemos permitido corregir la acentuación y suprimir consonantes dobles. 
_- Crónicas moriscas. Leyendas de la conquista de España, traducidas por Luis Miguel Báez Díaz. Granada: Ediciones Miguel Sánchez, 1974 (2002).

MAdDEN, Lionel, Robert Southey: The Critical Heritage. London: Routledge, 1972.

MenÉNDEZ Y Pelayo, Marcelino, Obras completas de Menéndez y Pelayo: Estudios sobre el teatro de Lope de Vega. III: IX. Crónicas y leyendas dramáticas de España: El último godo. Consejo Superior de Investigaciones Científicas, 1949.

NOEL, François, Dictionnaire de la fable Ou Mythologie Grecque, Latine, Egyptienne, Celtique, Personne, Syriaque,Indienne, Chinoise, Scandinave, Africaine, Américaine, Iconologique, etc., Paris: chez Le Normand, 1801.

SÁEz HeRMOSILlA, Teodoro, La traducción poética a prueba: exégesis y autocrítica. León: Secretariado de Publicaciones, 1998.

SAGLIA, Diego, Poetic Castles in Spain: British Romanticism and Figurations of Iberia. Amsterdam/Atlanta, GA., Rodopi, 2000.

SOUTHEY, Robert, Roderick the last of the Goths. A Tragic Poem, two volumes. Edinbourg-London: James Ballantyne \& Co. 1814.

- Roderick, The Last of the Goths: A Tragic Poem. En: The Poetical Works of Robert Southey, Complete in One Volume, London, 1884.

—- Selections from the Letters of Robert Southey, edited by his son-inlaw, John Wood Warter, in 4 volumes. London, Longman, volume II, 1856.

SPECH, William, Robert Southey. New Haven: Yale University Press, 2006. 